\title{
Body Image And Religiosity In Adolescents: A Comparation Between Public And Private High School Students
}

\author{
Widana Primaningtyas ${ }^{1}$, Anak Agung Alit Kirti Estuti Narendra Putri ${ }^{1}$, \\ Heni Hastuti ${ }^{1}$ \\ 1. Medical Faculty of Sebelas Maret University, Surakarta, Indonesia
}

Coresponding author : widanadoctor@gmail.com.

\begin{abstract}
Background: There are many literatures have reported the link between religiosity and health outcomes. Body image come as someones' perceptions towards their body, also being influenced by religiosity. The aims of this study was to compare body image in adolescents between private (Islamic) and public (mix religion) high schools, beside the similar study in Indonesia have not yet reported.

Method: This was a cross sectional design study using Body Shape Questionnaire (BSQ) and Duke University Religion (Durel) Index questionnaire. We used purposive sampling for sampling technique. The data collected from one private (I) and one public (II) senior high schools in Surakarta, Indonesia. An independent-samples t test was conducted to compare the BSQ score and Durel index between both schools.

Result: Total 150 questionnaires were distributed to both schools, only 116 questionnaires filled completely. There was a significant difference in the Durel index between school I $(M=25.90, S D=2.82)$ and II $(M=24.70, S D=1.55) ; t(114)=2.84, p=0.005$. But there was not a significant difference in the BSQ score between school $I(M=77.00, S D=26.16)$ and II $(M=79.86, S D=26.67) ; t(114)=-0.58, p=0.561$.

Conclusion: These results showed that the students who studying in a private senior high school have a higher religiosity compare to those who studying in public senior high school. The higher religiosity in private schools' gave them lower score on BSQ compare to public schools', but the mean differences were not statistically significant.
\end{abstract}

Keywords: body image; adolescents; body shape

\begin{abstract}
ABSTRAK
Background: Religiusitas dan hubungannya dengan outcome kesehatan telah dibahas dalam berbagai studi. Salah satu outcome kesehatan yang berhubungan dengan religiusitas adalah body image. Tujuan dari studi ini adalah untuk membandingkan body image pada remaja di sekolah menengah atas privat (Islami) dan sekolah umum (berbagai agama). Studi ini di Indonesia masih belum banyak ditemukan publikasinya.

Metode: Studi ini adalah studi observasional analitik dengan pendekatan cross sectional. Dua kuisioner digunakan sebagai alat ukur penelitian yaitu Body Shape Questionnaire (BSQ) dan Duke University Religion (Durel) Index questionnaire. Teknik sampling yang digunakan adalah purposive sampling. Data penelitian didapatkan dari 1 sekolah menengah atas privat (I) dan 1 umum (II) di Surakarta, Indonesia. Untuk analisis data dalam studi ini digunakan Independent-samples $t$ test untuk membandingkan skor BSQ dan Durel index dari dua sekolah tersebut.

Hasil: 150 kuisioner didistribusikan kepada remaja di kedua sekolah, hanya 116 kuisioner yang pengisiannya lengkap. Terdapat perbedaan yang signifikan dari skor Durel index antara sekolah I $(\mathrm{M}=25.90, \mathrm{SD}=2.82)$ dan II $(\mathrm{M}=24.70, \mathrm{SD}=1.55) ; \mathrm{t}(114)=2.84, \mathrm{p}=0.005$. Untuk skor BSQ antara sekolah I $(\mathrm{M}=77.00, \mathrm{SD}=26.16)$ dan II $(\mathrm{M}=79.86, \mathrm{SD}=26.67)$; $\mathrm{t}(114)=$ $0.58, \mathrm{p}=0.561$, ditemukan perbedaan mean, namun tidak signifikan secara statistik.
\end{abstract}


Kesimpulan: Hasil dari studi ini dapat menggambarkan bahwa remaja yang bersekolah di sekolah menengah atas privat mempunyai religiusitas yang lebih tinggi daripada di sekolah umum. Remaja di sekolah privat dilihat dari nilai Mean, mempunyai hasil body image yang lebih baik berdasarkan skor BSQ dibandingkan dengan sekolah umum, namun tidak signifikan secara statistik.

Keywords: body image; remaja; bentuk tubuh

\section{INTRODUCTION}

Body image is someone perception about how they look like physically and their description, feeling and thinking of the body looks and size according to their own mind. ${ }^{1,2}$ The ideal body image is changing during the times and it's influenced by culture and society, modernisation, and globalization. ${ }^{3}$ Nowadays, generally the dominant beauty standard is what the Western culture emerged. The ideal beauty for woman is the "thin ideal" and for man is "all about muscle".,

Meanwhile, the adolescents are on the critical stages of transition between childhood and adulthood, with all their complexity because of the biopsychosocial changing, they are easy to get dissatisfy with their look. This negative body image could lead them fall into psychopathology condition that influence their behaviour. ${ }^{6}$ This negative body image can change someone behaviour, they tend to have unsual eating behaviour, even eating disorder because of their desire to be thin. They could have lower self esteem, depression, even suicide. $^{7}$

Religiosity is defined as an organised system consist of belief, ritual, practise and symbols that have been designed to facilitate someone with their God. ${ }^{8}$ In this matter the religion is the prior foundation in influence someones behaviour. The spirituality and religiosity of an individu can influence their perception on how they value their body. With a strong belief and religiosity an individu can be protected from negative behaviour as a result from negative body image. ${ }^{2,9,10}$ High belief in the religion and the good "connection" with God is related to lower anxiety towards their body shape. ${ }^{11,12}$

Indonesia, is one of an Asian country that being influenced aswell by globalization, including the Western culture. As a country with the biggest Muslim population in the world, the researchers decided to know more about the comparation on body image subject among the adolescents from different religiosity level. Hence, we did this pilot study in two different schools (differences on religion, environment and the schools' character), one private Islamic high school and one public (mix religion) high school.

\section{METHODS}

\section{Sample}

Participants for this study were students on a public senior high school $(\mathrm{N}=57)$ and private senior high school $(\mathrm{N}=59)$, all of them are in their mid and late period of adolescents. A public senior high school in Surakarta, Central Java, Indonesia, was chosen because of this public school is one of the favourite high school with A grade according to our government, also in this school the students variation in race and religion are many. The next school to be chose was a private senior high school in the same district, because it consist of homogeny religion students (Islam) and its also a grade A school. This private high school give more concern on students religiosity by including the Islamic content in their curricula. Because we designed this study for specific population as mentioned 
before, hence we used purposive sampling here. The students in their mid and late period of adolescents, no psychological issue, no physical deformity, and agree to participate then become the sample of this study. The sample size was calculated for the adolescents who have negative perception about their body, with 95\% Confidence Interval, 5.8\% proportion in the population and 0.05 absolute precision, until we got the minimum sample size was 84 . An ethical clearance was done and ethically approved by The Health Research Ethics Committee Dr. Moewardi General Hospital/ School of Medicine Sebelas Maret University of Surakarta (512/VI/HREC/2016).

\section{Instruments}

The following instruments were used in this study. The first instrument we used was Body Shape Questionnaire (BSQ) that was published by Cooper et al. in 1986. Its consist of 34 questions and each question is scored one to six with "never $=1$ " and "always $=6$ ", so the lowest score will be 34 and the highest will be 204. We chose BSQ as an instrument for body image assessment because it can define someone's perception about their body for both sexes by changing some questions in the questioner and also capable to detect someone with typical anorexia nervosa and bulimia nervosa $^{13,14}$. The classification of full BSQ scores are: less than 80 (no concern with shape), 80-110 (mild concern with shape), 111140 (moderate concern with shape), and above 140 (marked concern with shape). The score above 129 show the possibility of someone have bulimia ${ }^{14}$. The BSQ used before by another researchers and was translate into Indonesian. For validity concern, this BSQ was tested for its validity using specificity ( $\mathrm{Sp}$ ) and sensitivity ( $\mathrm{Se}$ ) measured based on Figure Rating Scale standard (FRS) with Sp 90.4\% and $\mathrm{Se} 75 \%$, and reliability test result was $0.875^{14}$.
Duke University Religion (Durel) Index questionnaire was chosen to be the next instrument in this study. This questionnaire can be used for measuring the Organizational and Non Organizational Religious Activity (ORA and NORA), also Intrinsic Religiosity (IR) as well ${ }^{15}$. Durel questionnaire was written in English and then translated into Bahasa Indonesia by Indonesian bilingual academic person and then translated back into English by an American native speaker. Durel Index questionnaire consist of five items and its measurement based on Likert-like scale. Items number one and two were scored from "never $=1$ " until "few times a week=6" or "more than once a day $=6$ ". The items number three until five the scoring were "strongly disagree $=1$ " until "strongly agree $=5$ ". So the minimum score was five and the maximum score was 27 . The higher the score, showing higher religiosity. According to a study by Nurasikin et al the internal reliability of Durel$\mathrm{M}$ was moderate (Cronbach's alpha $=0.45)^{16}$. On the other hand, this study Cronbach's alpha was 0.37 . It was because the questionnaire only consist of five questions, and according to the previous study, questionnaire with more items will give higher coefficient alpha ${ }^{17}$.

\section{RESULT}

\section{Subject characteristic}

The samples from the private senior high school (I) were 59 adolescents, which $30.5 \%$ were males and $60.5 \%$ were females. Almost similar distribution on gender, samples took from public senior high school (II) were 57 adolescents, $36.8 \%$ were males and $63.2 \%$ were females. The samples from school II were consist of Islam, Christian, Chatolic (and others) students. Meanwhile the samples from school I were 100\% Muslim (Islam). 
Primaningtyas, et. al., Body Image And Religiosity In Adolescents: A Comparation Between Public And Private High School Students

Table-1. The distribution of the sample based on BSQ categories

\begin{tabular}{cllll}
\hline School & & BSQ (\%) & \\
& $<80$ & $80-110$ & $111-140$ & $>140$ \\
\hline I & 55.9 & 33.2 & 10.2 & 1.7 \\
II & 54.4 & 36.8 & 5.3 & 3.5 \\
\hline
\end{tabular}

I: private senior high school; II: public senior high school; BSQ: Body Shape Questionnaire

Based on table-1 all the majority samples from both schools were on the first category (no concern with shape). But the percentage of the sample in the other categories (mild concern and marked concern with shape) were bigger in the school II. Meanwhile for the Durel Index questionnaire, we categorised the sample into two groups (dichotomy) based on the median score $(\mathrm{Me}=26)$. The distribution of the sample based on Durel Index can be seen in table-2.

Table-2. The distribution of the sample based on Durel Index

\begin{tabular}{ccc}
\hline School & \multicolumn{2}{c}{ Durel Index $(\%)$} \\
& $<26$ & $>=26$ \\
\hline I & 33.9 & 66.1 \\
II & 43.9 & 56.1
\end{tabular}

I: private senior high school; II: public senior high school; Durel Index: Duke University Religion Index.

\section{Body Image}

In order to determine the comparison of body image between the school I and II we conducted an independent-samples $t$ test.

We could see wether there were statistifically relevan different between them in table-3.

Table-3. Result of independen-samples t test of body image based on BSQ score between public senior high school (II) and private senior high school (I) adolescents

\begin{tabular}{ccc}
\hline Group & Mean & SD \\
\hline I & 77.00 & 26.16 \\
II & 79.86 & 26.67
\end{tabular}

Note : $\mathrm{t}(114)=-0.58 \mathrm{p}=0.561$

\section{Religion Index}

We described the samples' religiosity using Durel Index questionnaire, then we conducted an independent-samples $t$ test to compare the result between school I and II. The result can be seen on table-4. We could see at the table-4, the mean of Durel Index from group I was higher than group II and the $\mathrm{p}$ value was 0.005 , so it was statistically significant.

Table-4. Result of independen-samples t test of religiosity based on Durel Index between public senior high school (II) and private senior high school (I) adolescents

\begin{tabular}{ccc}
\hline Group & Mean & SD \\
\hline I & 25.90 & 2.82 \\
II & 24.70 & 1.55 \\
\hline
\end{tabular}

Note: $\mathrm{t}(114)=2.84, \mathrm{p}=0.005$

\section{DISCUSSION AND CONCLUSION}

The higher score on BSQ showing the higher concern on body shape and appearance. In this study we found majority of the adolescents from both schools were on the first category based on BSQ score, they were have no concern with shape. We could say that they tend to have positive body image and satisfy with their physical appearance. We also found 45.6\% adolescents from public senior high school and $44.1 \%$ from private senior high school were have mild concern until marked concern with shape, or the have negative body image. Moreover, from public school we found adolescents with BSQ score $>129$, means they have possibility of bulimia or another eating disorder. The BSQ Mean score of the adolescents on private school was lower than 
the adolescents in public school. Although the comparison result between both schools on body image based on BSQ score was not statistically significant $\quad(p=0.561)$. The religiosity based on Durel Index also different between private and public senior high school. As expected the religiosity of private (Islamic) senior high school students $(M=25.90$, $\mathrm{SD}=2.82)$ were higher than the public senior high school $(\mathrm{M}=24.70, \mathrm{SD}=1.55)$ and it was significantly different $(\mathrm{p}=0.005)$.

These results were consistent with few earlier research. The study among adolesecents in Brazil showed $71.1 \%$ of the subjects that have positive body image and $28.9 \%$ have negative body image ${ }^{5}$. Another study results showed that in general people, they tend to have positive body image and lower in body dissatisfaction compare to the people that live in United States ${ }^{18}$. But another study took in Singapore showed that most of the subjects (51\%) have negative body image compare with the subjects who satisfy with their physical appearance (49\%), it's very interesting on how this result could be different among the countries in different cultural background ${ }^{2}$. Commonly known that Singapore location is really close to Indonesia but the cultural background and society are slightly different, so that probably could give different results in this same subject.

In the term of religiosity the study by Zhang on 2012 showed that there were subjects with negative body images in both group (one group saying that they were "religious" and another group saying that they were "free thinkers"), but among the subjects in the religious group only $12 \%$ of them got body dissatisfaction while in the other group 23\% of them had negative body image. Around 6\% subjects from the religious group got extremely dissatisfied and 26\% of the free thinkers group got extremely dissatisfied ${ }^{2}$. This results matched with our study, it explained that religiosity play a role in counter body dissatisfaction among adolescents. Meanwhile in our study, the sample in private senior high school, that more religious compare to the public school, had a lower BSQ Mean score, it meant they tend to become more satisfy with their looks. In the private Islamic senior high school all the female students wear hijab (their hair and body covered) so that probably give them less pressure from following the ideal beauty standard by Western society. In this case, religion could be as a protective factor while it comes on body and appearance attitude among the female Muslim. Indeed a sociocultural background in body image field play a really strong role ${ }^{19}$.

The sample size of this study was not big enough, it might could influence the statistical results. Also this study result probably could not be generalised into different demographic characteristic. Despite, this study could give a brief description on comparison of the religiosity and body image of the adolescents in private Islamic and public senior high school in Indonesia.

Since the prevalence of body dissatisfaction keep rising up, body image problem also become a serious public mental health problem ${ }^{20}$. This study identified subjects with probability having an eating disorder in the public school, which probably this finding just like an iceberg phenomenon. Hence a massive and positive campaign about body image should be arranged. Another form of support from the school that could give greater impact to the students about body image is when they put this body image term in to their curricula. They have to integrate the spiritual and cognitive development in a balance way in order to make the students realise that they were created in their best looks and focus to build their character.

\section{REFERENCE}

1. Honigman, Roberta dan David J. Castle. Living with Your Looks. Victoria: University of Western Australia Press; 2007. 
2. Zhang, K.C. What I Look Like: College Women, Body Image, and Spirituality. Journal of Religion and Health 2012; 52:1240-1252.

3. Martin, J.B. The Development of Ideal Body Image Perceptions in the United States. Lippincott Williams \& Wilkins: Nutrition Today 2010; 45(3): 98- 110.

4. Berg P, Paxton SJ, Keery H,Wall M, Guo J,Sztainer DN. Body dissatisfaction and body comparison with media images in males and females. Body Image 2007; 4: 257-268.

5. MirandaVPN, Contiz MA, de Carvalho PHB, Bastos RR, Ferrira MEC. Body image in different periods of adolescence. Rev Paul Pediatr 2013; 32(1):63-9.

6. Natsuaki M.N., Samuels D., and Leve L.D. The Oxford Handbook of Identity Development : Puberty, Identity, and Context: A Biopsychosocial Perspective on Internalizing Psychopathology in Early Adolescent Girls. Oxford University Press; 2016. Downloaded from:

http://www.oxfordhandbooks.com/view/10.10 93/oxfordhb/9780199936564.001.0001/oxford hb-9780199936564-e-005

7. Latzer, Y., Tzischinsky, O., Azaiza, F. Disordered Eating Related Behaviors among Arab Schoolgirls In Israel: An Epidemiological Study. Wiley Interscience: International Journal of Eating Disorders 2007; 40(3): 263 270.

8. Koenig H, Raja D, and Carson V. Handbook of Religion and Health 2. New York: Oxford University Press; 2012.

9. Mussap, A.J. Strength of faith and body image in Muslim and non-Muslim women. Mental Health, Religion \& Culture 2008; 2 (12): 121 127.

10. Avant SK, Warburton LA, Margolin A. Spiritual and religious support in recovery from addiction among HIV-positive injection

11. drug users. J Psychoactive Drugs 2001; 33:3945.

12. Allport G, Ross J. Personal religious orientation and prejudice. Journal of Personality and Social Psychology 1967; 5(4):432.

13. Akrawi D, Bartrop R, Potter U, Touyz S. Religiosity, spirituality in relation to disordered eating and body image concerns: A systematic review. Journal of Eating Disorders 2015; 3:29.

14. Pook M, Brunna TC, Elmar B. Evaluation and comparison of different versions of Body
Shape Questionnaire. Psychiatry Research 2006; 158:67-73.

15. Septiadewi D and Briawan D. The application of Body Shape Questionnaire (BSQ) and Figure Rating Scales (FRS) method for measuring body perception of adolescent females. Gizi Indonesia 2010; 33(1): 29-36.

16. Koenig $\mathrm{HG}$ and Bussing $\mathrm{A}$. The Duke University Religion Index (DUREL): a five items measure for use in epidemiological studies. Religion 2010; 1:78-85.

17. Nurasikin MS, Aini A, Aida SAA, Ng CG. Validity and reliability of the Malay version of Duke University Religion Index (DUREL-M) among a group of nursing student. MJP Online Early 2010; 02-12-10.

18. Shuttleworth M (2009). Internal consistency reliability. Retrieved on 3 November 2010.

19. Jansen A. A Cross Cultural Study of Body Image and Eating Habits Between Genders. UW-L Journal of Undergraduate Research 2008; IX: 1-4.

20. Durovic D, Tiosavljevi M, Sabanovi H. Readiness to accept Western standard of beauty and body satisfaction among Muslim girls with and without hijab. Scandinavian Journal of Psychology 2016; 12315: 1-6.

21. Dion J, Blackburn ME, Auclair J, Laberge L, Veillette S, Graudreault M, Vachon P, Perron M, Touchette E. Development and aetiology of body dissatisfaction in adolescent boys and girls. International Journal of Adolescence and Youth 2015; 20(2):151-166. 